\title{
Macrophytes Assemblages in Mountain Lakes of Alerce Andino National Park
}

\author{
( $41^{\circ} \mathrm{S}$, Lakes Region, Chile).
}

\section{Macrófitas assemblages em lagos de montanha de Alerce Andino National Park (41 ${ }^{\circ}$ S, Região dos Lagos, Chile).}

\author{
Enrique Hauenstein ${ }^{1,2^{*}}$, Mario Romero-Mieres ${ }^{1} \&$ Patricio Acevedo ${ }^{3,4}$. \\ 1- Universidad Católica de Temuco, Facultad de Recursos Naturales, Escuela de Ciencias Ambientales, \\ Laboratorio de Ecología Aplicada y Biodiversidad, Casilla 15-D, Temuco, Chile \\ 2- Núcleo de Estudios Ambientales, UC Temuco \\ 3- Universidad de La Frontera, Departamento de Ciencias Físicas, Casilla 54-D, Temuco, Chile \\ 4- Center for Optics and Photonics, Universidad de Concepción, Casilla 4012, Concepción, Chile \\ * Author para correspondencia, email: ehauen@uct.cl
}

\begin{abstract}
The lakes studied (Chapo, Sargazo, Chaiquenes and Triángulo) are located in the Alerce Andino National Park $\left(41^{\circ} 30 ' \mathrm{~S}, 71^{\circ} 32^{\prime} \mathrm{W}\right)$, Chile. An inventory of the aquatic and riparian species was performed between December 2010 and January 2011. A null model analysis was done to determine the existence of regulatory factors of species associations, and the Jaccard index was applied to determine floristic similarities. It identidied 23 species, the high number was reported (14) and the most introduced species number (4) were reported at Sargazo lake, whereas the low species number was observed in Triángulo lake with three species. The analysis of the null model revealed the presence of regulatory factors in one of the three simulations. However, in the other two simulations, the species associations appeared to be random, presumably because many species were repeated at the study sites. According to the Jaccard index, Triángulo Lake is noticeably different from the other lakes, probably due to its marked oligotrophy.

Keywords: oligotrophy, mesotrophy, macrophytes, null model, lakes, Patagonia, Chile.
\end{abstract}

\section{RESUMO}

Os lagos estudados (Chapo, Sargazo, Chaiquenes e Triángulo) estão localizados no Parque Nacional Andino Alerce $\left(41^{\circ} 30^{\prime} \mathrm{S}, 71^{\circ} 32^{\prime} \mathrm{W}\right)$, Chile. Um inventário das espécies aquáticas e ribeirinhas foi realizada entre dezembro de 2010 e janeiro de 2011. Uma análise modelo nulo foi feito para determinar a existência de fatores de regulação de associações de espécies, e o índice de Jaccard foi aplicado para determinar similaridade florística. Ele identidied 23 espécies, o número elevado foi relatado (14) eo número de espécies mais introduziu (4) foram relatados em Sargazo lago, enquanto que o baixo número de espécies foi observada no lago Triángulo com três espécies. A análise do modelo nulo revelou a presença de factores de regulação em um dos três simulações. No entanto, nas outras duas simulações, as associações de espécies parecia ser aleatória, presumivelmente porque muitas espécies foram repetidas nos locais do estudo. De acordo com o índice de Jaccard, Triángulo Lake é visivelmente diferente dos outros lagos, provavelmente devido ao seu oligotrofia marcada.

Palavras-chave: oligotrofia, mesotrophy, macrófitas, modelo nulo, lagos, Patagonia, Chile. 


\section{INTRODUCTION}

The Chilean lakes of the north Patagonia are characterized by their oligotrophy, due to the native forest and chemical composition of the soil of their basin that avoid the nutrient entry from the land to the water, mainly in unpolluted mountain zones that have perennial native forests in their surrounding basins (Steinhart et al., 2002; De los Ríos-Escalante et al., 2012). Nevertheless, an oligotrophy to mesotrophy transition has been observed in some lakes located mainly between 38 to $41^{\circ} \mathrm{S}$, due to the replacing of the native forest of their basin by agricultural zones, towns and industries (Soto, 2002; Villalobos et al., 2003; Woelfl et al., 2003; Woelfl, 2007). One of the biotic components that can be an indicator of trophic status is the assemblage of macrophytes (Hauenstein et al., 2002, 2011; Nagasaka, 2004; Li et al., 2009). We define macrophytes according to Ramírez \& Stegmeier (1982). The macrophytes in Chilean inland waters have numerous endemic species (79.3\%) and a low amount of introduced species $(20.7 \%)$; there are endangered species that would need more studies about conservation topics (Hauenstein, 2006), especially if we consider that some Chilean lagoons close to coastal zones, and small stands of plants in the lakes have human intervention (Soto, 2002; Hauenstein et al., 2008), with the consequent alterations in macrophytes assemblages (Hauenstein et al., 2002; Ramírez \& San Martín, 2006).

According to this point of view, the macropytes and riparian assemblages are not random, that means that the regulator factors are deterministic. The absence of regulator factors, this is random distribution in species co-occurrence, is the basis of null models; one of these models used presence and absence of species to determine the absence of deterministic factors as regulator of co-occurrence species (Gotelli, 2000; Tiho \& Johens, 2007). These null models are more robust in comparison with deterministic models (Gotelli, 2000). The aim of the present study is applying a null model analysis based in a presenceabsence species matrix for determining the absence regulator factors to explain species associations in macrophytes of lakes in Alerce Andino National Park.

\section{MATHERIAL AND METHODS}

Between January 2010 to January 2011 we worked in four lakes of a mountainous zone with Nothofagus nitida, N. pumilio, $N$. dombeyi and Fitzroya cupressoides forests: Chapo Lake, adjacent at Alerce Andino National Park (4127,5' S 72³0' W; 241 m a.s.l); the second site was Sargazo lake at the

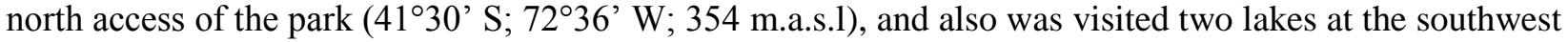
access of the park, Chaiquenes ( $41^{\circ} 33^{\prime}$ ' S; $72^{\circ} 32^{\prime} \mathrm{W}$; 538 m.a.s.l) and Triangulo lake $\left(41^{\circ} 35^{\prime}\right.$ S; $72^{\circ} 32^{\prime}$ W; 285 m.a.s.l), these lakes are characterized by their marked oligotrophy and presence of native forest in their 63urrounding basin (Steinhart et al., 2002; De los Ríos-Escalante et al. 2012).

The riparian and macrophyte species were collected and identified, according to Matthei (1995), Espinoza (1996) and Hoffmann et al. (1997); the scientific names updated by means of Zuloaga et al. (2008) and in the following page web: (http://www.ipni.org/). The taxonomical classification and the phytogeographical origin, according to Marticorena \& Quezada (1985), and the helophytes and hydrophytes taxa, according to the classification of Ramírez \& Stegmeier (1982) and Ramírez \& San Martín (2006).

The degree of human intervention was determined on the basis, according to the proposal of Hauenstein et al. (1988) and the scale of assessment proposed by González (2000), who used the phytogeographical origin (percentage relationship between native and the introduced species) to establish the degree of human disturbance of a specific area.

The comparison of the data set gathered is useful to test the hypothesis that species reported are non-randomly associated. For this, we use the "C score" index (Tiho \& Johens, 2007), which determines the presence-absence co-occurrence based on presence -absence matrices for zooplankton species in the sample. According to Gotelli (2000) and Tiho \& Johens (2007) the presence/absence matrix was analysed as follows: (a) fixed-fixed: in this algorithm, the row and the column sums of the original matrix are preserved. Thus, each random community contains the same amount of species as the original community (fixed column), and each specie occurs with the same frequency as in the original community (fixed row). 
In this case, it is not prone to type I errors (falsely rejecting the null hypothesis) and it has a good power for detecting the non-randomness (Gotelli, 2000; Tiho \& Johens, 2007). (b) Fixed-equiprobable: in this simulation, only the row sums are fixed, whereas the columns are treated as equiprobable. This null model treats all the samples (columns) as equally suitable for all species (Tiho \& Johens, 2007; Gotelli, 2000). (c) Fixed-proportional: in this algorithm, the total of species occurrence is maintained as in the original community, and the probability that a specie occurs in a sample (= column) is proportional to the total column for that sample (Gotelli, 2000; Tiho \& Johens, 2007). The data were analysed with the Ecosim program version 7.0 (Gotelli \& Entsminger, 2009). Finally, it was applied a Jaccard index for determining the similarities between the studied sites (Gotelli \& Graves, 1996), this analysis was applied using the software Biodiversity Pro. 2.0.

\section{RESULTS AND DISCUSSION}

The results of the floristic analysis revealed the presence of 23 species (21 vascular plants and two non vascular plants) and, in decreasing order, the lakes with more species were Sargazo, Chaiquenes, Chapo and Triángulo with 14; 5; 5 and 3 species respectively. Table 1 shows the complete and current catalogue. The more represented species are Magnoliopsida with 43.5\% and Liliopsida with 39.1\%; algae y pteridophytes both have $8.7 \%$ each one. The total flora includes 4 classes, 16 families and 21 genus, with a different distribution between the lakes: two classes, 10 families and 14 genus were found in Sargazo Lake, in Chaiquenes Lake, three classes, 4 families and 4 genus, in Triángulo Lake, two classes, 3 families and 3 genus, and finally in Chapo Lake, three classes, 5 families and 5 genus (Table 1, Fig. 1).

In the Great Lakes of the region of the Andean precordillera so-called "Araucanians", whose waters are oligotrophic and the lakes have a much larger surface area in study (Campos, 1984; Soto \& Campos, 1995; Soto, 2002, Woelfl 2007), there has been a greater variability in the richness of flora. While the lakes Llanquihue and Cayutué presented a richness of species similar to the lakes of this study, 40 and 37 respectively (Hauenstein et al., 1991, 1992), the lakes Villarrica, Caburgua and Calafquén are richer in diversity of species, registering 65, 64 and 69 species respectively (Hauenstein et al., 1996, 1998), of which the only one that presents characteristics of mesotrophy condition is Villarrica Lake, with values of $87 \mathrm{ug} \mathrm{L}^{-1}$ of $\mathrm{NO}_{3}$ and $20.4 \mathrm{ug} \mathrm{L}^{-1}$ of total phosphorus (Soto \& Campos, 1995). The low amount of species of the four lakes surveyed confirms the oligotrophic character of their waters.

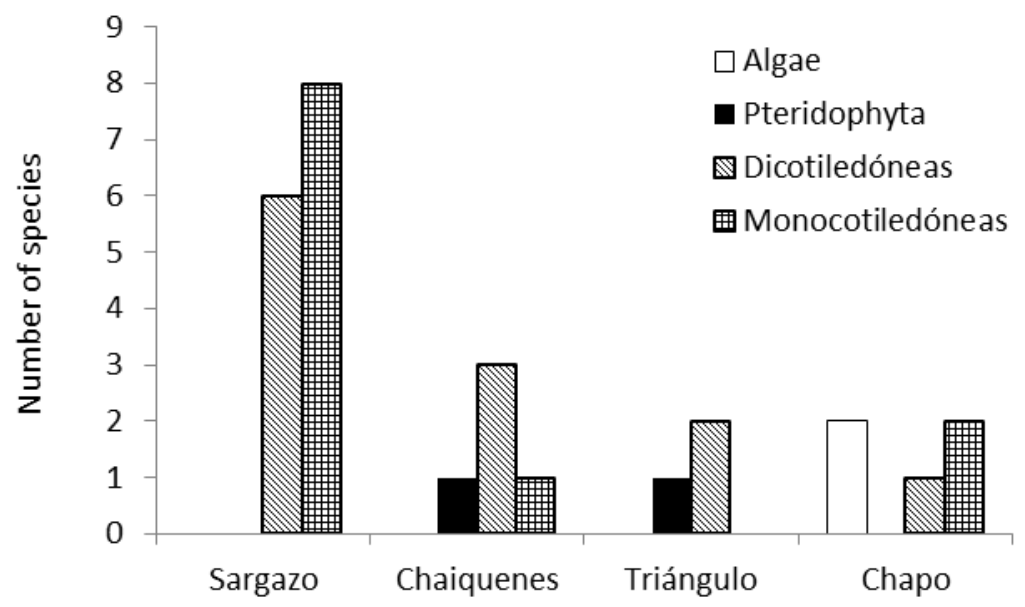

Figure 1

Classification of macrophytes reported in the studied sites. 
Sustainability, Agri, Food and Environmental Research 4(3), 2016: 62-69

ISSN: 0719-3726

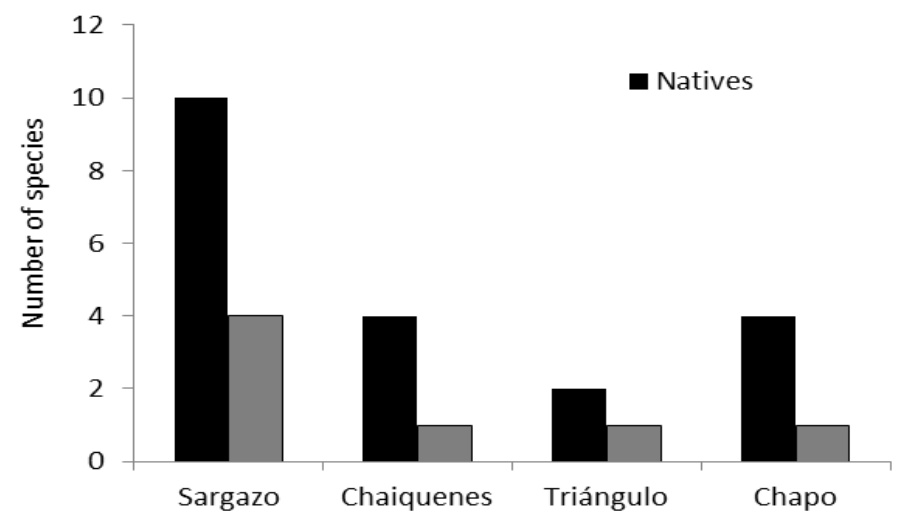

Figure 2

Phytogeographical origin of the flora in the studied sites.

The phytogeographical origin shows that in the four lakes surveyed the native species are dominant (Table 1, Fig. 2). The relatively low percentage of non-native species indicates a certain anthropized degree on their banks (Hauenstein et al., 1988, 2011), which would below, according to the scale of González (2000), to the category of "low human disturbance" for the three lakes of higher altitude (Chaiquenes, Triángulo, Sargazo), with one introduced species, these lakes have access difficults and it is probably that the presence of one introduced species would be to accidental introductions due tourism activities; instead the Chapo Lake has a high introduced species that would be associated to human intervention due rural communities and salmoniculture activities, that has classified it in the category of "high human disturbance".

The results of null model analysis revealed the absence of regulator factors in species assemblages for Fixed-Fixed simulation $(\mathrm{P}>0.05)$ and Fixed-Proportional $(\mathrm{P}>0.05)$ whereas these results do not correspond to the Fixed-Equiprobable simulations $(\mathrm{P}<0.05)$. A possible cause would be the presence of many repeated species (Table 2). In according to Bray-Curtis index, revealed low similarities for studied lakes being the most similar Chaiquenes and Sargazo lakes with $10 \%$, and consecutively Triángulo and Chapo lakes (Fig. 3).

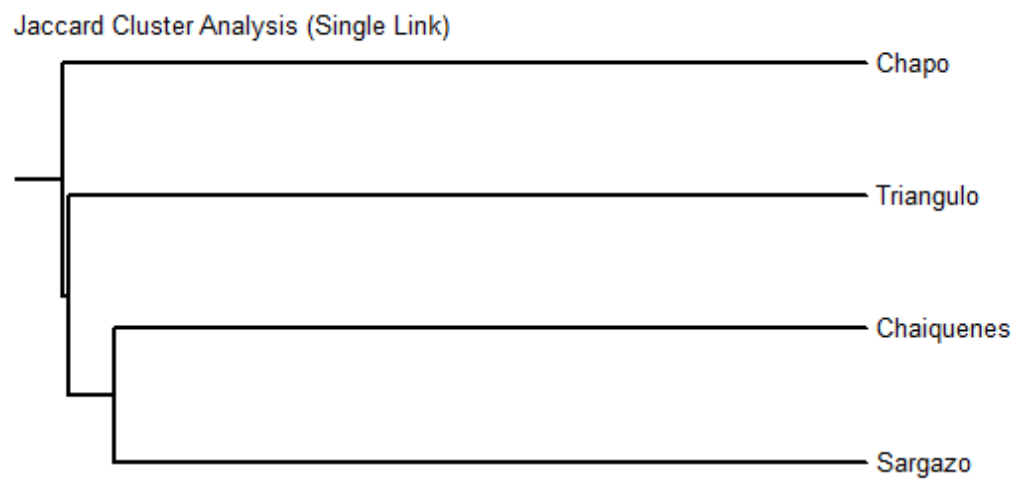

$\begin{array}{lll}0 . \% \text { Similarity } & 50 . & 100\end{array}$

Figure 3

Dendrogram according to Jaccard index for the four lakes studied. 
Sustainability, Agri, Food and Environmental Research 4(3), 2016: $62-69$

ISSN: 0719-3726

Table 1.

Catalogue of macrophytes in four lakes of the Alerce Andino National Park. X: presence, empty space:

absence. OF: phytogeographical origin, N: native, I: introduced

\begin{tabular}{|c|c|c|c|c|c|c|}
\hline Classification/Scientific name & Family & $\mathrm{OF}$ & Sargazo & Chaiquenes & Triangulo & Chapo \\
\hline \multicolumn{7}{|l|}{ Algae } \\
\hline Oscillatoria sp. & Oscillatoriaceae & & & & & \\
\hline Nitella sp. & Characeae & & & & & \\
\hline \multicolumn{7}{|l|}{ Pteridophyta } \\
\hline Blechnum cordatum (Desv.) Hieron. & Blechnaceae & $\mathrm{N}$ & & $\mathrm{x}$ & & \\
\hline Blechnum penna-marina (Poir.) Kuhn & Blechnaceae & $\mathrm{N}$ & & & $\mathrm{x}$ & \\
\hline \multicolumn{7}{|l|}{ Magnoliopsida (Dycotiledoneae) } \\
\hline Dichondra sericea $\mathrm{Sw}$. & Convolvulaceae & $\mathrm{I}$ & $\mathrm{x}$ & & & \\
\hline Hydrocotyle sp. & Apiaceae & $\mathrm{N}$ & $\mathrm{x}$ & & $\mathrm{x}$ & \\
\hline Myosotis scorpioides $\mathrm{L}$. & Boraginaceae & I & & & $\mathrm{x}$ & \\
\hline Myriophyllum aquaticum (Vell.) Verdc. & Haloragaceae & $\mathrm{N}$ & & $\mathrm{x}$ & & \\
\hline Plantago major L. & Plantaginaceae & I & $\mathrm{x}$ & & & \\
\hline Polygonum hydropiperoides Michx. & Polygonaceae & I & & & & $\mathrm{x}$ \\
\hline Prunella vulgaris $\mathrm{L}$. & Lamiaceae & I & $\mathrm{x}$ & & & \\
\hline Ranunculus minutiflorus Bert. ex Phil. & Ranunculaceae & $\mathrm{N}$ & & $\mathrm{x}$ & & \\
\hline Ranunculus repens $\mathrm{L}$. & Ranunculaceae & I & $\mathrm{x}$ & $\mathrm{x}$ & & \\
\hline Symphyotrichum vahlii (Gaudich.) G.L.Nesom & Asteraceae & $\mathrm{N}$ & $\mathrm{x}$ & & & \\
\hline \multicolumn{7}{|l|}{ Liliopsida (Monocotyledoneae) } \\
\hline Agrostis magellanica Lam. & Poaceae & $\mathrm{N}$ & $\mathrm{x}$ & & & \\
\hline Carex sp. & Cyperaceae & $\mathrm{N}$ & $\mathrm{x}$ & & & \\
\hline Distichlis sp. & Poaceae & $\mathrm{N}$ & & & & $\mathrm{x}$ \\
\hline Eleocharis bonariensis Nees & Cyperaceae & $\mathrm{N}$ & $\mathrm{x}$ & & & \\
\hline Juncus procerus E.Meyer & Juncaceae & $\mathrm{N}$ & $\mathrm{x}$ & & & $\mathrm{x}$ \\
\hline Polypogon australis Brongn. & Poaceae & $\mathrm{N}$ & $\mathrm{x}$ & & & \\
\hline Potamogeton strictus Phil. & Potamogetonaceae & $\mathrm{N}$ & $\mathrm{x}$ & & & \\
\hline Schoenoplectus californicus (C.A.Mey.) Soják & Cyperaceae & $\mathrm{N}$ & $\mathrm{x}$ & $\mathrm{x}$ & & \\
\hline Scirpus inundatus (R.Br.) Poir. & Cyperaceae & $\mathrm{N}$ & $\mathrm{x}$ & & & \\
\hline
\end{tabular}

Table 2.

Results of the null model analysis for studied sites. $\mathrm{P}<0.05$ denote the presence of non random (or regulator) factors as regulator of the species association.

\begin{tabular}{llllll}
\hline & Mean index & Observed index & Variance & Standard effect size & $\mathrm{P}$ \\
\hline Fixed-fixed & 0.739 & 0.727 & $<0.001$ & -0.408 & 0.442 \\
Fized-proportional & 0.726 & 0.727 & 0.011 & 0.011 & 0.458 \\
Fixed-equiprobable & 0.862 & 0.727 & 0.001 & -3.034 & 0.013 \\
\hline
\end{tabular}


The results about littoral macrophytes are similar to the descriptions of mountain lakes; where the macrophytes are present contributing a high oxygen concentration (Nagasaka, 2004; Li et al., 2009). Nevertheless Chapo lake has low species number in spite of their transition from oligotrophy to mesotrophy (Villalobos et al., 2003; Woelfl et al., 2003), these patterns are similar to other lakes of the same category, with changes in trophic status, where ultraoligotrophic lakes have a low amount of species and abundance (Nagasaka, 2004; Li et al., 2009).

Similar results of low amount of macrophytes species associated to diversity were observed for coastal wetlands in the Araucanía region with different trophic status due to human intervention (Hauenstein et al., 2002; Peña-Cortés et al., 2006). By his part, Ramírez \& San Martín (2006) signal that the aquatic flora is scarce in water bodies oligotrophic and that this tends to situate in slots well delimited in the littoral zone, process known as zoning, which depends of habit of the species (submerged, floating, emergent).

These results are the first observations for pristine mountain lakes of the north Patagonia, because this condition generates a different regulator mechanism in comparison to lakes of the north hemisphere (Soto, 2002; Steinhart et al., 2002).

\section{ACKNOWLEDGEMENTS}

The present paper was funding by the projects DGIPUCT 2009-3-6, MECESUP 0804 and it was recognized the logistic support of staff of Alerce Andino National Park CONAF-Chile (Forestry National Corporation, Chile) and M.I for her valuable comments for improve the manuscript.

\section{REFERENCES}

Campos, H. 1984. Limnological study of Araucanian lakes (Chile). International Vereinigung Theoretishe und Applied Limnolology, 22: 1319-1327.

De Los Ríos,-Escalante, P. Hauenstein E., Romero-Mieres M., \& Acevedo P., 2012. Use of null models to explain crustacean zooplankton assemblages in waterbodies of Alerce Andino National Park. Crustaceana 85(6): 713-722.

Espinoza, N. 1996. Malezas presentes en Chile. Instituto de Investigaciones Agropecuarias (INIA). Centro Regional de Investigaciones Carillanca, Temuco, 219 pp.

González, A. 2000. Evaluación del recurso vegetacional en la cuenca del río Budi, situación actual y propuestas de manejo. Tesis Licenciatura en Recursos Naturales, Universidad Católica de Temuco, 110 pp.

Gotelli, N.J. 2000. Null models of species co-occurrence patterns. Ecology, 81(9): 2606-2621.

Gotelli, N.J. \& Entsminger G.L.., 2009. EcoSim: Null models software for ecology. Version 7. Acquired Intelligence Inc. and Kesey-Bear. Jericho, VT 05465. URL: http://garyentsminger.com/ecosim.htm.

Gotelli, N.J. \& Graves G.R., 1996. Null models in ecology. Smithsonian Institution Press, Washington DC., 357 pp.

Hauenstein, E., 2006. Visión sinóptica de los macrófitos dulceacuícolas de Chile. Gayana, 70(1): 16-23. 
Sustainability, Agri, Food and Environmental Research 4(3), 2016: 62-69

ISSN: 0719-3726

Hauenstein, E., González, M., Leiva, L., \& Falcón L., 1998. Diagnóstico del estado de contaminación de los lagos Calafquén y Caburgua. Informe Final Proyecto FNDR N 20107905 IX Región, Chile, 76 pp.

Hauenstein, E., González, M., Peña-Cortés, F., \& Muñoz-Pedreros A., 2002. Clasificación y caracterización de la flora y vegetación de los humedales de la costa de Toltén (IX Región, Chile). Gayana Botánica, 59(2): 87-100.

Hauenstein, E., Ramírez, C., Latsague, M. \& Contreras D., 1988. Origen fitogeográfico y espectro biológico como medida del grado de intervención antrópica en comunidades vegetales. Medio Ambiente, 9: $140-142$.

Hauenstein, E., Ramírez, C., González M. \& San Martín C., 1991-1992. Comparación de la flora macrofítica de tres lagos del centro-sur de Chile (Budi, Llanquihue, Cayutué). Revista de Geografía de Valparaíso, 22-23: 175-193.

Hauenstein, E., Peña-Cortés, F., Bertrán, C., Tapia, J. \& Schlatter R., 2008. Comparación florística y estado trófico basado en plantas indicadoras de lagunas costeras de la región de La Araucanía, Chile. Ecología Austral, 18(1): 45-53.

Hauenstein, E., Ramírez, C., González, M., Leiva, L. \& San Martín C., 1996. Flora hidrófila del lago Villarrica (IX Región, Chile) y su importancia como elemento indicador de contaminación. Medio Ambiente, 13: 88-96.

Hauenstein, E., Barriga, F. \& De Los Ríos-Escalante P., 2011. Macrophytes assemblages in mountain lakes of Huerquehue National Park ( $39^{\circ} \mathrm{S}$, Araucanía Region, Chile). Latin American Journal of Aquatic Research 39(3): 593-599.

Hoffmann, A., Kalin M., Liberona F., Muñoz, M. \& Watson J., 1997. Plantas altoandinas en la flora silvestre de Chile. Edición Fundación Claudio Gay, Santiago, 281 pp.

Li, K.Y., Liu, Z.W. \& Guan, B.H, 2009. Effects of nutrient levels in surface water and sediment of the growth of the floating-leaved macrophyte Trapa maximowiczii: implication for management of macrophytes in East Bay of Lake Taihu. Limnology, 11(2): 95-101.

Marticorena, C. \& Quezada M., 1985. Catálogo de la flora vascular de Chile. Gayana Botánica, 42: 5-157.

Matthei, O. 1995. Manual de las malezas que crecen en Chile. Edición Alfabeta Impresiones, Santiago, 545 pp.

Nagasaka, M. 2004. Changes in biomass and spatial distribution of Elodea nuttallii (Planch.) St. John, an invasive submerged plant, in oligomesotrophic Lake Kizaki from 1999 to 2002. Limnology, 5(3): 129-139.

Peña-Cortés, F., Gutiérrez P., Rebolledo G., Escalona M., Hauenstein, E., Bertrán, C., Schlatter, R. \& Tapia J., 2006. Determinación del nivel de antropización de humedales como criterio para la planificación ecológica de la cuenca del lago Budi, IX Región de la Araucanía, Chile. Revista de Geografía Norte Grande, 36: 75-91.

Ramírez, C. \& San Martín C., 2006. Diversidad de macrófitos chilenos. In: I. Vila, A. Veloso, R. Schlatter \& C. Ramírez (eds). Macrófitos y vertebrados de los sistemas límnicos de Chile. pp. 21-72. Editorial Universitaria, Santiago, Chile. 
Sustainability, Agri, Food and Environmental Research 4(3), 2016: 62-69

ISSN: 0719-3726

Ramírez, C. \& Stegmeier E., 1982. Formas de vida en hidrófitos chilenos. Medio Ambiente, 6: 43-54.

Soto, D. 2002. Oligotrophic patterns in southern Chile lakes: the relevance of nutrients and mixing depth. Revista Chilena de Historia Natural, 75(2): 377-393.

Soto, D. \& Campos H., 1995. Los lagos oligotróficos del bosque templado húmedo del sur de Chile. In: J.J. Armesto, C. Villagrán \& M.K. Arroyo (eds.). Ecología de los bosques nativos de Chile.pp. 317-334 Editorial Universitaria, Santiago, Chile.

Steinhart, G.S., Likens, G.E. \& Soto D., 2002. Physiological indicators of nutrient deficiency in phytoplankton of southern Chilean lakes. Hydrobiologia, 489: 21-27.

Tiho, S. \& Johens J., 2007. Co-occurrence of earthworms in urban surroundings: a null models of community structure. European Journal of Soil Biology, 43(2): 84-90.

Villalobos, L., Woelfl, S., Parra, O. \& Campos H., 2003. Lake Chapo: a base line study of a Deep, oligotrophic North Patagonian lake prior to its use for hydroelectric generation: II Biological properties. Hydrobiologia 510(1/3): 225-237.

Woelfl, S., Villalobos, L., Parra, O., Steffen, W. \& Campos H., 2003. Lake Chapo: a base line study of a Deep, oligotrophic North Patagonian lake prior to its use for hydroelectric generation: II Physical and Chemical properties. Hydrobiologia 510(1/3): 217-224.

Woelfl, S., 2007. The distribution of large mixotrophic ciliates (Stentor) in deep North Patagonian lakes (Chile): first results. Limnologica 37(1): 28-36.

Zuloaga, F., Morrone, O. \& Belgrano M., 2008. Catálogo de las plantas vasculares del Cono Sur (Argentina, Sur de Brasil, Chile, Paraguay). URL:

http://www2.darwin.edu.ar/Proyectos/FloraArgentina/FA.asp 